DOI: $10.11649 / \mathrm{abs} .2019 .005$

\author{
Frederik H. Bissinger \\ Stockholm University \\ Stockholm \\ frederik.bissinger@balt.su.se \\ https://orcid.org/0000-0002-4918-1901
}

\title{
Lithuanian language discourses and family language policies of Lithuanian families in Sweden: A case study
}

\section{Introduction}

Extensive emigration has been affecting the Lithuanian population since the end of the twentieth century. However, the restoration of independence in 1990 and the EU entry in 2004 gave it a boost (Ramoniené, 2015b) and led to a negative net migration (Statistics Lithuania, 2016). As a result, Lithuania is among the top EU member states with the highest emigration rates in relation to their population (Ramoniene, 2015b, referring to Barcevičius, 2012), and these numbers are often perceived as the most serious non-military threat to the Lithuanian cultural identity, demographic development and economic growth (Ramoniene, 2015b, referring to Martinaitis \& Žvalionyte, 2007). Apart from the United States, the United Kingdom and Germany, the top ten destinations also include the Scandinavian countries (Europos migracijos tinklas, 2016).

In spite of this, present-day Lithuanian emigrants and their efforts to maintain linguistic and cultural heritage, as well as the acquisition of the Lithuanian language among their children, have not as yet been the subject of extensive research. The existing studies mainly focus on the United States (e.g. Jakaité-Bulbukiené, 2015; Norvilas, 1990; Tamošiūnaite, 2008) and the United Kingdom (e.g. Blažiené, 2016;

This is an Open Access article distributed under the terms of the Creative Commons Attribution 3.0 PL License (creativecommons.org/licenses/by/3.0/pl/), which permits redistribution, commercial and non-commercial, provided that the article is properly cited. (c) The Author(s) 2019. 
Liubiniene, 2010). Only recent research started to take a globally comparative view (Ramonienè, 2015a).

The present research project addresses this gap and studies Lithuanian immigrant families in Sweden and their language maintenance efforts. This article presents the first part of the data collected in the project. As in Jakaite-Bulbukiene (2015), the focus lies on family language policies as the family is the key domain for the maintenance of minority languages (Pauwels, 2016). This small-scale case study relies on a discourse analysis approach applied in the framework of linguistic ethnography. Apart from interview data, it also considers data from participant observations and participant self-recordings.

Family language policy is an important aspect in the study of language maintenance as it "deepen[s] our understanding of home language maintenance processes as well as how heritage language learners are best supported" (King, Fogle, \& Logan-Terry, 2008, p. 909). Drawing on Cooper's (1989) general outline of language policy as such, King et al. summarize the concerns of family language policy with the following question: "Which caretakers attempt to influence what behaviors of which family members for what ends under what conditions by what means through what decision-making process with what effect?" (King et al., 2008, p. 910, original emphasis). However, this begs the question whether it is only caretakers who set a family language policy. Considering that it is "a dynamic and changeable life-long process" (Schwartz \& Verschik, 2013, p. 17), children might also be in a position to negotiate and contribute to its construction. The aim of this study is therefore to gain a better understanding of how family language policy is constructed and implemented in Lithuanian families in Sweden from a micro-perspective. The first research question of the current case study is the following: (1) Who employs what strategy in order to achieve what?

Another aspect that can be considered when investigating family language policies is "the influence of discourses produced outside the home" (Mirvahedi \& Macalister, 2017, p. 223) as they have an impact on the actual beliefs and behaviour of family members. This article tries therefore to glimpse at Lithuanian language discourses to investigate how they might have influenced the beliefs of Lithuanian parents in an immigrant family in Sweden, and how they might resonate in the discourses of its language policy. In Lithuania, language discourses are framed by a rather protectionist language ideology, which is clearly apparent, for example, in the institution of "language police" that controls that Lithuanian is correctly used in the public domain (Vaicekauskiene \& Šepetys, 2016). There are several characteristics that underlie this Lithuanian language ideology. One main feature is that the Lithuanian language and identity is permanently perceived as being under threat even after the fall of the Soviet Union and the restoration of independence - which is apparent in the activity of the State Commission of the Lithuanian Language. 
Consequently, it is controlled that Lithuanian standard language is used, and that it is used correctly. Furthermore, purism is part of the ideology as loanwords are rarely allowed in order to protect the language from foreign influences (Vaicekauskiene \& Šepetys, 2016). The current case study seeks to investigate whether the Lithuanian language discourses that the parents encountered in Lithuanian society are reflected in their family language policy. The second research question of this case study is therefore: (2) What language discourses touching on the family language policy can be identified?

The next part presents the linguistic ethnographical approach applied in the current case study. It is followed by a brief introduction of the data and the researched family. The main parts analyse and discuss discourses that have been identified and that might affect the family language policy, as well as the discourse strategies that the family members employ. The final part concludes the findings of the study.

\section{Linguistic ethnography}

The approach adopted in the current study is that of linguistic ethnography, i.e. "an interpretive approach which studies the local and immediate actions of actors from their point of view and considers how these interactions are embedded in wider social contexts and structures" (Copland \& Creese, 2015, p. 13). As Rampton, Maybin and Roberts (2015) emphasize, linguistic ethnography focuses "on how language is used as part of social practice, deeply connected with relationships, identity, power and cultural values" (p. 39). Analysing observations and recordings of everyday linguistic interactions within families may provide insights into how identities are constructed and negotiated within the family by family members. Understanding these personal interactions as linguistic practices may make it possible to gain indepth insights into the family language policy. Furthermore, personal interaction may also reveal linguistic power relations and show: firstly, who exercises power with what motives and with what effect; secondly, if there are other layers of power that affect the family from outside, such as discourses; and, thirdly, if there is a linguistic hierarchy, e.g. in regard to Swedish, Lithuanian or other languages, as well as dialects or certain styles.

This case study pays attention to the social relationships between the family members, their histories as well as their linguistic behaviours, beliefs and expectations. As in other linguistic ethnography studies, different methods of data collection are applied to examine "the micro-level, minute-to-minute processes of socialisation, learning and construction of identities" (Maybin, 2009, p. 76). How- 
ever, the focus is not on the school context as in Maybin (2009) but on the family. In order to acquire manifold data, different methods of data collection are applied: self-recordings of the participants, participant observations, interviews and a family language tree. The data collected using the first three methods are the object of discourse analysis, while the latter provide background information about the family members.

\section{The data}

The following parts present the results of the case study in question. The data were collected during the first months of fieldwork at a Lithuanian heritage school, where classes took place every second Sunday, and where the researcher established contact with the participants. Apart from the data of the family language tree, which provide an overview of the family members' linguistic resources, an interview (ca. $80 \mathrm{~min}$.) was conducted in Lithuanian at the participants' home. The interview, recorded and later transcribed, covered the following topics: migration background, life in Sweden, language practices and development within the family, as well as culture and identity. The family was also asked to do some self-recordings. The researcher suggested they should record several scenarios on a daily basis for the period of a week, including events such as breakfast, dinner, homework, playtime or the way to school. Unfortunately, in this case the self-recorded data are rather limited (ca. $10 \mathrm{~min}$.), which comes as a confirmation that this method is highly dependent on the participants. Despite these limitations, the data provide interesting insights which should be shared to stimulate further research. The participant observations were conducted during meetings with the family in the Lithuanian heritage language school and at home. They focused on language practices of the participants and their language management efforts. The study material includes field notes of these observations (6 conducted at school and 2 at home).

The first section below introduces the researched family. The following sections present four language discourses that have been identified in the data and analyse the strategies of the participants aiming to negotiate language practices.

\section{The family}

As had been expected, the family language tree and the interview data provided the background information that they aimed at mapping. The family under study 
has been living in Sweden for four years. It consists of the parents, Ona ${ }^{1}$ and Jonas, and their daughter, Ieva (6 years old), as well as the mother's son (16 years old) from a previous relationship. ${ }^{2}$ They migrated from Lithuania to Sweden in search of work and better opportunities. Both parents come from the easternmost part of Lithuania, the region called Aukštaitija. Their fathers are from the west of the country (the region called Žemaitija), and their mothers - from the east (Aukštaitija). Both spouses know Lithuanian, Russian, Swedish and English. The mother completed a higher education programme and has an office job. She has attended all levels of Swedish courses for immigrants (SFI - Svenska för invandrare), which are offered by Swedish municipalities free of charge. The father has a secondary education and works in the service sector. He learned Swedish while working in his first job in Sweden. The son knows Lithuanian, Swedish and English. The daughter knows Swedish and Lithuanian (the order as indicated by the parents); she also attends a Lithuanian heritage language school. As the following discourse analysis of the data illustrates, not all these language resources are equally available and used within the family.

\section{Discourse of language control and employed strategies}

The first identified discourse that is reflected in the family language policy is the discourse of language control (Vaicekauskienè \& Šepetys, 2016), which is taken up by the mother: she is the active family policy maker and implementer. My observations, self-recordings made by the family members and the interview data indicate that the participants first and foremost use Lithuanian and to a certain degree Swedish. From the researcher's point of view, there is no evidence of dialectal varieties of Lithuanian in the data. The parents explained in the interview that they used the standard variety because their parents had originally come from different regions, which is why both of them had spoken standard rather than dialectal Lithuanian in their childhood. Focusing on the actual use of languages, it can be stated that the family members use the resources to a different degree. In general, it is the mother who is best aware of language use at home and who expects every family member to speak only Lithuanian.

By and large, the other family members appear to meet the mother's expectations regarding the family home language use. Yet, especially the daughter some-

\footnotetext{
1 The names of all participants of the study have been changed to protect their anonymity.

2 The son is left out of this analysis due to lack of further data, hence the focus lies on the parent-daughter interactions.
} 
times speaks Swedish at home, as confirmed by the parents during an interview. On such occasions, the mother tries to control the situation and tells her to speak Lithuanian, and the father often echoes her words. Example 1 below illustrates such an instance; it is extracted from an interview conducted in Lithuanian: the daughter was busy drawing and suddenly interrupted the interview by asking for more paper:

Example 1: During an interview ${ }^{3}$

Daughter: Kan jag ha några papper?

Can I have some paper?

Mother: (...) Ieva, kaip lietuviškai? (.) Paprašyk tėčio.

(...) Ieva, how is it in Lithuanian? (.) Ask dad.

Father: Kaip lietuviškai?

How is it in Lithuanian?

Daughter: Kitą popierius.

Another paper.

Mother: Kitą popierių.

Another paper.

This example, which is a case of a very short "language negotiation sequence" (Auer, 1984, p. 20), shows that the family members have their assigned parts in this discourse. The daughter takes the turn and switches the code from Lithuanian to Swedish, which is a violation of the mother's policy and a challenge to her control. The mother does not accept the switch; she tells her to use Lithuanian, selects the next speaker, and gives the turn back to the daughter. The father takes his turn and supports the mother with his echo question. The daughter switches back to Lithuanian. Overall, the mother can be identified as the controller who applies a monolingual strategy (Lanza, 1992), while the father often echoes her commands, and the daughter challenges this policy with her code-switching but then obeys the commands. The mother is the active parent that sets and controls the policy that only Lithuanian should be used within the family. She clearly communicates her norms and expectations, which is considered a crucial factor for successful language maintenance (Jakaité-Bulbukienè, 2015). The fact that, on the contrary, the father is rather passive becomes more evident in the following example:

Example 2: Watching TV (observer's note taken at home)

The father and the daughter are watching online TV in Lithuanian, dubbed versions of Lego Batman, Trolls and Pokémon. The daughter tells her father in Swedish what clips to choose and gives their brief summaries in Swedish. Her father does not insist that she should say it in Lithuanian. While they are watching Pokémon, she identifies

${ }^{3}$ In all transcripts Lithuanian is marked in bold font, Swedish in italic, and English translations are unmarked. 
several Pokémon by comparing them with her collector cards. Her mother enters the room and the daughter stops the clip to show her the Pokémon and to tell her about them in Swedish. Her mother then insists that she should say it again in Lithuanian.

Here, it becomes clearer that the mother is the active family language policy maker and implementer. The father, in turn, takes a rather passive role in the implementation, which creates a certain inconsistency with the "Lithuanian-only" policy set by the mother. Until the mother enters the room the daughter speaks Swedish and is not restricted by her father in any way. The father is less active in controlling the daughter's language use. Even though he supports the mother in Example 1 above, he takes a rather passive role. When the daughter talks to him in Swedish (Example 2), he does not insist that she should speak Lithuanian. He is less restrictive about the language use at home: from time to time he even switches to Swedish himself, which, according to him, happens automatically, and which was criticized by the mother in an interview. ${ }^{4}$ Interestingly, then, he is less engaged in the discourse of language control and sometimes disregards, to a certain degree, the mother's policy. While the mother fosters the use of Lithuanian and actively restricts the use of Swedish, his passivity opens up space for the latter. This divergence could be a drawback since consistency is viewed as an important factor for optimal outcomes of a family language policy (King et al., 2008).

Nevertheless, it needs to be stressed that the mother's strategy to ask the daughter to repeat what she said in Lithuanian is consistent and quite successful. The daughter does not resist the mother's commands. The case of this family does not resemble some of those examined in Tuominen's study (1999), where immigrant parents with low proficiency in the host society's language supported its use at home to learn it from their children. As pointed out above, the parents know Swedish well and therefore they are able to keep control over their language practices. However, they react differently to code-switching, which needs to be further investigated in future studies. Accompanying the family over a longer time span may also provide insights into whether their language practices will change, and whether Lithuanian will become the only language at home.

\section{Discourse of correct language use and employed strategies}

The discourse of correct language use (Vaicekauskienè \& Šepetys, 2016) could also be identified as being reflected in the family language policy and is taken up by the mother. Yet, this is not necessarily specific for Lithuanian migrant families.

\footnotetext{
${ }^{4}$ Father: "taip, gaunasi, kad automatiškai kalbu” [yes, it appears, that I talk automatically].
} 
In Example 1 above, this discourse appears when the daughter switches back to Lithuanian and makes a grammatical mistake when she asks for more paper: the mother subtly corrects the daughter's mistake by repeating the correct form. ${ }^{5}$ This seems to be her usual strategy, as it can also be seen in Example 3, extracted from a self-recording made on the way to the Lithuanian heritage language school.

Example 3: On the way to the Lithuanian school

Mother: $\quad$ o ką po mokyklèlès nori daryti?

And what would you like to do after school?

Daughter: (eh) Noriu i "Junibacken".

(eh) I want to "Junibacken".

Mother: Nori važiuoti i "Junibacken"?

You want to drive to "Junibacken"?

Daughter: Taip.

Yes.

Mother: $\quad$ O kas ten tau patinka?

And what do you like there?

Daughter: "Sagotåget"

"Sagotåget" = The Story Train

Mother: $\quad$ O kaip lietuviškai tai pasakyti galima?

And how can one say that in Lithuanian?

Daughter: Pasaku traukinys.

The Story Train.

Mother: $\quad$ Pasakų traukinys. O kas ten pasakų traukinyje yra, kur jisai važiuoja? The Story Train. And what is there in the Story Train which drives there?

Daughter: I pasakus.

To stories.

Mother: I pasakas. I kokias pasakas?

To stories. To what kind of stories?

Daughter: (eh) Yra ị Stokholmą.

(eh) It is to Stockholm.

Mother: Aha, ir važiuoja ị Stokholmą.

Aha, and it drives to Stockholm.

Daughter: Ir matome Karlsoną.

And we see Karlson.

Mother: (laughs) kuris gyvena ant stogo.

(laughs) who lives on the roof.

Daughter: $/ / \mathbf{m h m} / /$

${ }^{5}$ In Example 1: a mismatch of case: Kitą (Acc $\mathrm{Sg}$ ) popierius (Nom $\mathrm{Sg}$ ) vs Kitą (Acc $\mathrm{Sg}$ ) popierių (Acc Sg). 
This example shows that the mother relies on other-initiated repairs by replacement (Kitzinger, 2013): she initiates replacing incorrect words by the daughter. She makes her translate "Sagotåget" (the Story Train) into Lithuanian and asks what there is. This demand to use a proper Lithuanian equivalent could also be related to the discourse of "purism" (Vaicekauskiene \& Šepetys, 2016), ${ }^{6}$ as the use of a Swedish loanword is discouraged in order to protect the Lithuanian language from foreign influences. The daughter has some problems with the gender of the Lithuanian word for "story" (pasak-a, Nom Sg Fem): she uses a masculine ending ( ${ }^{*}$ pasak-us, Acc Pl Masc). In this case, the mother corrects her daughter's speech by providing the correct form (pasak-as, Acc Pl Fem). Interestingly, the daughter does not respond to the correction and does not repair her utterance. However, the mother does not demand that she should and, hence, the daughter does not relate to this discourse.

Another mistake in Example 3 might stem from the influence of the Swedish language but, interestingly, is not identified as such by the mother. Asked about the kind of stories the train goes to, the daughter thinks for a while and answers "Yra ị Stokholmą" (It is to Stockholm). As it makes no sense at the first glance, the mother corrects the sentence to 'ir važiuoja i Stokholmą' (and it drives to Stockholm) in her repetition. The daughter does not react to the mother's repair here either. However, it can be argued that the daughter's utterance was an instance of code-mixing: the Lithuanian directional preposition "ip" (to) is actually the Swedish local preposition "i" (in), and the actual meaning of the sentence would be: "it [the Story Train] is in Stockholm". One argument in favour of this interpretation is the more complex expression of locations in Lithuanian than in Swedish, and my observations of other children of Lithuanian descent in Sweden who make similar mistakes.

\section{Discourse of identity threat and employed strategies}

The third identified discourse affecting the family language policy is the discourse of identity threat (Vaicekauskienè \& Šepetys, 2016). The mother, again, has an active part here: she stresses the Lithuanian heritage and tries to foster a sense of belonging. Example 4 below has been recorded from memory: during a participant observation visit at home, the mother (Ona) talked about the Lithuanian school and criticized children who speak Swedish during the breaks; the literature on the subject provides similar observations concerning Lithuanian schools in the United States, e.g. Norvilas (1990) and Tamošiūnaitè (2008).

${ }^{6}$ The "purism" discourse occurred only once in the data, which is why it is not discussed in more detail. 


\section{Example 4: 'Good Girl'}

Ona and I are having a cup of coffee and talk about the Lithuanian heritage language school. Ieva is playing in the same room. Ona says that she is a bit upset by the boys who speak Swedish at the school. Ieva hears that and comments:

Daughter: Aš bandau kalbèti lietuviškai su berniukais. $\mathbf{O}$ tada jie tik: 'Vad?'

I try to speak Lithuanian with the boys. And then they are just like: 'What?'

Mother: $\quad$ Tu šaunuolè. Gerai, kad kalbi lietuviškai.

You are a good girl. Good that you speak Lithuanian.

Example 4 is interesting because it is an instance of "identity claim" (De Fina, Schiffrin, \& Bamberg, 2006, p. 3) performed by the daughter (Ieva). The mother emphasizes, again, the need to use Lithuanian instead of Swedish with those other children who know both languages and, hence, to use the opportunity to speak Lithuanian to Lithuanians, a factor of shared heritage, and thus maintain a Lithuanian identity. The daughter joins the conversation and takes a turn where she actively constructs her Lithuanian identity by contrasting herself with the boys who speak Swedish in the Lithuanian school. The mother, in turn, praises the daughter for her identity claim.

However, observations at the Lithuanian heritage language school show that the daughter sometimes does speak Swedish with her peers. She is not always under the control of her mother there and she seems to be more empowered to display other identities to a certain degree. Hence, Lithuanian does not seem to be a significant factor for the identity constructed with some peers at the heritage language school. Rather, this peer identity is connected with the language of the host society, as could also be seen in other studies about Lithuanian heritage speakers mentioned above (Liubinienè, 2010; Norvilas, 1990; Tamošiūnaitè, 2008). This indicates that different (shifting) identities are constructed depending on local and social contexts (Pérez-Milans, 2016). That is, one identity is constructed by the mother and her daughter at home, while other identities are constructed with peers at school.

Yet, the daughter is not always free to do the latter independently: the mother tries to intervene when she notices that she performs other identities that would be related to the Swedish language; this can be seen in Example 5 below:

Example 5: Observation at the Lithuanian school

The break has started and the few children that are around today (some families are on holidays) are coming out of the classrooms. Ieva and her friend Vydas take seats next to their parents and eat their breakfast. Having finished his breakfast, Vydas takes out a small folder with his Pokémon cards and catches Ieva's attention. They begin a discussion in Swedish about the cards, which ends up in a small argument over whether 
one of Vydas' cards is a fake or not. Ieva tries to convince him by showing him the differences between his and her card. The parents are talking to each other and do not seem to notice the situation. Suddenly, Ona realises what is going on and addresses Vydas to tell him that he should speak Lithuanian ("Vydai, kalbėk lietuviškai!" - "Vydas, speak Lithuanian!"). He doesn't listen and continues in Swedish and so does Ieva. Ona addresses Ieva now and tells her to speak Lithuanian (“Ievute, kalbèk lietuviškai!” "Ieva, speak Lithuanian!"); Ieva’s father, Jonas, also gets involved: he supports Ona by repeating what she said (“Ieva, kalbèk lietuviškai!” - “Ieva, speak Lithuanian!”). Ieva switches to Lithuanian but Vydas continues in Swedish. His mother Beatričè now comments to me: "O čia lietuvių mokykla" - "And here is the Lithuanian school", but she doesn't address the children. In the meantime, Ieva starts talking to Vydas in Swedish again. Ona gives up her involvement and sums up that Ieva's stronger language seems to be Swedish.

As soon as the mother has noticed that her daughter speaks Swedish with the boy, she intervenes trying to stop her and, hence, controls the language use. Interestingly, she first addresses the boy and not her own daughter. According to my observations, he tends to speak more Swedish than Lithuanian at the heritage school, which might explain her move to address him first. She addresses her daughter then and tells her to speak Lithuanian; the father, again, echoes, as discussed above in Example 1. The girl first obeys and switches to Lithuanian for a short while, as if symbolically "switching sides" (Auer, 1984, p. 23), but then switches back to Swedish. The mother, interestingly, gives up and does not try to regain control over the situation.

\section{Discourse of language threat and employed strategies}

The fourth discourse that is related to the family language policy under consideration is the discourse of language threat (Vaicekauskiene \& Šepetys, 2016). As Lithuanian is in a minor position in Sweden, the danger of its loss is greater than in Lithuania. This is related to the general problem of limited domains where a heritage language can be used, which has been discussed by Pauwels (2016). Since the opportunities to use Lithuanian in Sweden are limited, according to the mother it should be used whenever possible in order to foster its maintenance. Swedish, then, is only used with those who do not understand Lithuanian, which means that the family speaks Lithuanian with everybody who understands it, as Example 6 below shows. The mother states her social norms here, which she also tries to implement in the family. This norm is reflected in her policy and is related to the discourse of language control. As shown above, the daughter does not always comply with the mother's norm. Interestingly, the father, who, like his wife, has spent most of his life in Lithuania, does not seem to relate to that discourse either. 
Example 6: About the Swedish language

Mother: Kai mes nusprendėme gyventi Švedijoje, mes supratome, kad kalba yra pirmas [dalykas]... nes nemokant kalbos, tai nežinau kažkaip sudètinga, man atrodo, visais. [...] Kadangi mes stengiamès kalbèti švediškai. Jeigu yra kažkas, kuris nesupranta lietuviškai, tai švediškai mes kalbame.

When we decided to live in Sweden, we understood that language is the first [thing]... because without learning the language, that's, I don't know, somehow complicated with everything, it appears to me. [...] Because we try to speak Swedish. If there is someone who doesn't understand Lithuanian, then we speak Swedish.

Furthermore, it needs to be stressed that the mother's policy must not be misunderstood as an act of general isolation from the host society. Rather, it is an attempt to prevent a possible language shift. She is clearly aware of the importance of Swedish for her own and her family's social life, which is illustrated in Example 6 above. However, the daughter arrived in Sweden when she was two years old and has encountered the Swedish education system most of her life, which can explain her more frequent use of Swedish at home. The mother emphasizes therefore the linguistic heritage and tries to foster a strong sense of belonging with Lithuanian, which Liubiniene (2010) identifies as an important factor in the maintenance of the language among children of Lithuanian emigrants. Children with weaker ties to Lithuanian language and culture are more likely to undergo a language shift towards the language of the host society.

To sum up, the discourse of language threat is interrelated with all other presented discourses. The fact that there is a limited number of domains where Lithuanian can be used, and that the dominant language, Swedish, enters these domains, can be perceived as a threat to the maintenance of Lithuanian. Consequently, this can be identified as the underlying element which connects it to the other presented discourses. This also explains why the mother tries to control and restrict language resources to ensure space for Lithuanian. Limited opportunities to use it can also explain the mother's reaction to mistakes: the daughter has limited input.

\section{Conclusion}

Even though this article is based on a case study of one Lithuanian family living in Sweden and thus has its limitations due to a lack of broader data, it provides insights into how family language policies can be shaped and implemented, and how they can influence linguistic practices. The study identified four language discourses within the analysed family language policy, which are parallel to the aspects of the Lithuanian language ideology described by Vaicekauskienè and Šepetys (2016). 
However, it is beyond the scope of this case study to conclude whether the Lithuanian language ideology influenced the family language policy, or whether the identified tendencies are rather general for immigrant minorities. Yet, the study could provide first insights that further research could connect to.

The discourse of language control was taken up by the mother, who actively applied a monolingual strategy and demanded that the other family members use only Lithuanian at home. The daughter sometimes tried to negotiate the language by switching to Swedish, but the mother successfully communicated the norm. In contrast, the father was rather passive: he only echoed the mother's norm but did not apply it himself. A longitudinal study could investigate if this inconsistency might prevent the expected outcome of the policy and change the pattern of language use at home.

The discourse of correct language use was applied by the mother, who reacted to the daughter's grammatical mistakes. However, the daughter did not follow when the mother corrected her utterances. Furthermore, it can be argued that some mistakes might be attributed to contact with Swedish. A future study should address these observations and investigate quantitatively if also other children, firstly, fail to react to their parents' repair strategies and, secondly, make grammatical mistakes that might be related to language contact.

The discourse of identity threat was also apparent: while the mother expected her daughter to construct a Lithuanian identity, the daughter tended to show different identities depending on social and local contexts. However, the mother tried to regulate her daughter's behaviour when she performed identities related to the Swedish language. A focus on how immigrant parents try to regulate their children's identities and how children perceive these regulations would therefore be of future interest.

The discourse of language threat was connected to the other discourses and concerned the issue of where to use a minority language. The dominant language was perceived to endanger the maintenance of Lithuanian, which should therefore be used whenever possible in anticipation of a language shift. In contrast, further studies should also focus on families where the use of Swedish is not as restricted as in this case. 


\section{Bibliography}

Auer, P. (1984). Bilingual conversation. Amsterdam: John Benjamins Publishing Company. https://doi.org/10.1075/pb.v.8

Barcevičius, E. (2012). Emigracija ir grị̌ztamoji migracija Vidurio ir Rytų Europoje: Sèkmès istorija ar žlugusi svajonè? In E. Barcevičius \& D. Žvalionytė (Eds.), Užburtas ratas? Lietuvos gyventoju grižtamoji ir pakartotine migracija (pp. 31-74). Vilnius: Vaga.

Blažienè, A. (2016). Lietuvių kalbos gramatinių ypatybių ịsisavinimo anglų kalbos aplinkoje sunkumai. Bendrine kalba, 2016(89). Retrieved October 23, 2017, from http://www. bendrinekalba.lt/Straipsniai/89/Blaziene_BK_89_straipsnis.pdf

Cooper, R. L. (1989). Language planning and social change. New York, NY: Cambridge University Press. https://doi.org/10.1017/CBO9780511620812

Copland, F., \& Creese, A. (2015). Linguistic ethnography: Collecting, analysing and presenting data. London: Sage. https://doi.org/10.4135/9781473910607

De Fina, A., Schiffrin, D., \& Bamberg, M. (2006). Introduction. In A. De Fina, D. Schiffrin, \& M. Bamberg (Eds.), Discourse and identity (pp. 1-24). Cambridge: Cambridge University Press. https://doi.org/10.1017/CBO9780511584459.001

Europos migracijos tinklas. (2016). Top 10 destinations. Retrieved September 8, 2016, from http://123.emn.lt/en/emigration/top-10-destinations

Jakaitè-Bulbukienè, K. (2015). Lietuviu emigrantu šeima: Kalba ir tapatybe் (Doctoral dissertation). Vilnius University, Vilnius.

King, K. A., Fogle, L., \& Logan-Terry, A. (2008). Family language policy. Language and Linguistic Compass, 2(5), 907-922. https://doi.org/10.1111/j.1749-818X.2008.00076.x

Kitzinger, C. (2013). Repair. In J. Sidnell \& T. Stivers (Eds.), The handbook of conversation analysis (pp. 229-256). Chicester: Wiley-Blackwell. https://doi.org/10.1002/9781118325001. ch12

Lanza, E. (1992). Can bilingual two-year-olds code-switch? Journal of Child Language, 19(3), 633-658. https://doi.org/10.1017/S0305000900011600

Liubiniene, N. (2010). Being a transmigrant in contemporary world: Lithuanian migrants' quests for identity. Acta Historica Universitatis Klaipedensis, 20, 24-36.

Martinaitis, Ž., \& Žvalionyte, D. (2007). Emigracija iš Lietuvos: Ką žinome, ko nežinome ir ką turètume žinoti. Retrieved February 25, 2014, from www.academia.edu/1480886/ Martinaitis_and_Zvalionyte_2007._Emigracija_is_Lietuvos_ka_zinome_ko_nezinome_ir_ka_turetumeme_zinoti

Maybin, J. (2009). A broader view of language in school: Research from linguistic ethnography. Children $\mathcal{E}$ Society, 23(1), 70-78. https://doi.org/10.1111/j.1099-0860.2008.00177.x

Mirvahedi, S. H., \& Macalister, J. (2017). Home: A confluence of discourses in multilingual linguistic ecologies. In J. Macalister \& S. H. Mirvahedi (Eds.), Family language policies in a multilingual world: Opportunities, challenges, and consequences (pp. 219-235). New York, NY: Routledge. https://doi.org/10.4324/9781315619552 
Norvilas, A. (1990). Which language shall we speak? Language choice among young Lithuanian bilinguals. Journal of Baltic Studies, 21(3), 215-230. https://doi. org/10.1080/01629779000000101

Pauwels, A. (2016). Language maintenance and shift. Cambridge: Cambridge University Press. https://doi.org/10.1017/CBO9781107338869

Pérez-Milans, M. (2016). Language and identity in linguistic ethnography. In S. Preece (Ed.), The Routledge handbook of language and identity (pp. 83-97). New York, NY: Routledge.

Ramonienè, M. (Ed.). (2015a). Emigrantai: Kalba ir tapatybe. Vilnius: Vilniaus universiteto leidykla.

Ramonienè, M. (2015b). Itvadas: Globalizacija, emigracija ir lietuvių kalba. In M. Ramonienè (Ed.), Emigrantai: Kalba ir tapatybe (pp. 9-15). Vilnius: Vilniaus universiteto leidykla.

Rampton, B., Maybin, J., \& Roberts, C. (2015). Theory and method in linguistic ethnography. In J. Snell, S. Shaw, \& F. Copland (Eds.), Linguistic ethnography: Interdisciplinary explorations (pp. 14-50). New York, NY: Palgrave Macmillan. https://doi. org/10.1057/9781137035035_2

Schwartz, M., \& Verschik, A. (2013). Achieving success in family language policy: Parents, children and educators in interaction. In M. Schwartz \& A. Verschik (Eds.), Successful family language policy: Parents, children and educators in interaction (pp. 1-20). Dordrecht: Springer. https://doi.org/10.1007/978-94-007-7753-8_1

Statistics Lithuania: Emigrants, immigrants. (2016). Retrieved September 8, 2016, from http://osp.stat.gov.lt/en/statistiniu-rodikliu-analize?portletFormName=visualization\&hash=3269db7c-cab7-4775-a39b-7e6c7ec8586a

Tamošiūnaite, A. (2008). The Lithuanian language in the United States: Shift or maintenance? Lituanus, 54(3), 60-78.

Tuominen, A. K. (1999). Who decides the home language? A look at multilingual families. International Journal of the Sociology of Language, 140(1), 59-76. https://doi. org/10.1515/ijsl.1999.140.59

Vaicekauskienė, L., \& Šepetys, N. (2016). Lietuviu kalbos ideologija: Norminimo idejų ir galios istorija. Vilnius: Naujasis Židinys-Aidai.

\title{
Lithuanian language discourses and family language policies of Lithuanian families in Sweden: A case study
}

\begin{abstract}
This case study shares first insights of the family language policy of a Lithuanian family in Sweden. It identifies Lithuanian language discourses that might affect this
\end{abstract}


policy and analyses discourse strategies applied by the family members. The aim is to shed some new light on the negotiation processes of family language policies that either support the maintenance of an ethnic language as the means of intra-family communication in immigrant contexts or, conversely, work against it. Applying a linguistic ethnographical approach, the study indicates that in this case the family language policy is mostly shaped by the mother in a protective and monolingual way in order to foster the maintenance of the Lithuanian heritage in anticipation of an external threat for Lithuanian language and identity.

Keywords: family language policy; language maintenance; Lithuanian language discourses; linguistic ethnography; Sweden

\section{Litewskie dyskursy językowe a polityki językowe litewskich rodzin w Szwecji. Studium przypadku}

\section{Streszczenie}

Niniejszy artykuł przedstawia wstępne uwagi analityczne dotyczące polityki językowej litewskiej rodziny mieszkającej w Szwecji. Autor identyfikuje litewskie dyskursy językowe, które mogą mieć wpływ na jej politykę językową, i analizuje strategie dyskursu stosowane przez jej członków. Celem studium jest nowe spojrzenie na procesy negocjacji rodzinnych polityk językowych (family language policies), które mogą być pomocne w utrzymaniu ojczystego języka jako środka komunikacji w rodzinach emigrantów lub temu nie sprzyjać. Przedstawione badania opierają się na metodach etnografii lingwistycznej (linguistic ethnography) i wykazują, że w tym przypadku rodzinna polityka językowa jest kształtowana głównie przez matkę, jest jednojęzyczna i ma charakter ochronny - jest nakierowana na zachowanie litewskiego dziedzictwa kulturowego w związku z przewidywanymi zagrożeniami zewnętrznymi dla języka litewskiego i tożsamości litewskiej.

Słowa kluczowe: rodzinna polityka językowa; zachowanie języka; litewskie dyskursy językowe; etnografia lingwistyczna; Szwecja

Frederik H. Bissinger is a co-tutelle PhD student in Baltic Studies at Stockholm University and in Languages of Northern Europe and the Baltics at Johannes Gutenberg University, Mainz. He teaches at Stockholm University. In 2017, he was the main organiser of the 5th Baltic Student Conference: Bridges in the Baltics, held 
at Stockholm University. His research interests include language acquisition and maintenance, language policies, and multilingualism.

Correspondence: Frederik H. Bissinger, Department of Slavic and Baltic Studies, Finnish, Dutch and German, Stockholm University, e-mail: frederik.bissinger@balt.su.se

Support of the work: The study was conducted at the author's own expense.

Competing interests: The author declares that he has no competing interests. 